\title{
Influence of selenium bio-fortification on nutritional compositions, bioactive compounds content and anti-oxidative properties of young ricegrass (Oryza sativa L.)
}

\section{Rattanamanee Chomchan ${ }^{1}$, Sunisa Siriponguutikorn ${ }^{2 *}$, Panupong Puttarak ${ }^{3}$ and Rungtip Rattanapon ${ }^{2}$}

${ }^{1}$ Interdisciplinary Graduated School of Nutraceutical and Functional Food, Prince of Songkla University, Hat-Yai, Songkla, Thailand; ${ }^{2}$ Department of Food Technology, Faculty of AgroIndustry, Prince of Songkla University, Hat-Yai, Songkla, Thailand; ${ }^{3}$ Department of Pharmacognosy and Pharmaceutical Botany, Faculty of Pharmaceutical Sciences, Prince of Songkla University, Hat-Yai, Songkhla, Thailand

Corresponding author: Sunisa Siripongvutikorn, PhD, Asst. Prof., Department of Food Technology, Faculty of Agro-Industry, Prince of Songkla University, Hat-Yai, Songkla, 90112, Thailand

Submission Date: December $10^{\text {th }}, 2016$, Acceptance date: March $26^{\text {th }}, 2017$, Publication date: March $31^{\text {st }}, 2017$

Citation: Chomchan R., Siripongvutikorn S., Puttarak P., Rattanapon R. Influence of selenium bio-fortification on nutritional compositions, bioactive compounds content and anti-oxidative properties of young ricegrass (Oryza sativa L.); Functional Foods in Health and Disease 2017; 7(3): 195-209

\footnotetext{
ABSTRACT

Background: Young ricegrass (Oryza sativa L.) can be introduced as a functional food product, as sprouts have gained significant interest in recent times due to their high nutritional values. Biofortification of selenium is one strategy to enhance plant bioactivity. However, the level of selenium used varies among species of plants. Thus, the proper level needs to be explored.

Objective: To investigate the influence of selenium bio-fortification on nutritional compositions, bioactive compounds content, and anti-oxidative properties of young ricegrass.

Methods: Sodium selenite ranging 0, 10, 20, 30, and $40 \mathrm{mg} \mathrm{Se/L} \mathrm{has} \mathrm{been} \mathrm{hydroponically} \mathrm{bio-}$ fortified into ricegrass, grown for 8 days, and then investigated for changes of growth characteristics, selenium content, accumulation of bioactive compounds, and anti-oxidative properties.
} 
Results: Results revealed that selenium bio-fortified exogenously increased the accumulation of selenium in ricegrass by $529 \%$ at $40 \mathrm{mg}$ Se/L treatment without negative changes in the leaves' biomass at the day they were harvested. However, the root part weight slightly decreased when the selenium level increased. Selenium at concentration of 10 and $20 \mathrm{mg} \mathrm{Se} / \mathrm{L}$ can stimulate the production of phenolic compounds and antioxidant activities in young ricegrass as measured by DPPH, ABTS, FRAP, and chelating assay. Conversely, the higher level of selenium fortification reducing the accumulation of phenolics in ricegrass may due to pro-oxidant expression.

Conclusion: Selenium bio-fortification can be used as a useful technique to improve quality of ricegrass plantation. $10 \mathrm{mg} \mathrm{Se} / \mathrm{L}$ treatment was an ideal to trigger the synthesis of phenolics which exhibited high antioxidant activities. However, $40 \mathrm{mg} \mathrm{Se} / \mathrm{L}$ treatment was the most effective for the production of Se plant foods.

Keywords: Antioxidant activities; Bio-fortification; Ricegrass; Selenium

\section{INTRODUCTION}

Sprouts or young plant of cereals, grains, or legumes are currently relevant and interesting functional foods, as these plants at the beginning of the growing stage are associated with large amount of quality bioactive compounds such as amino acids, trace elements, vitamins, and various phytochemicals [1]. Consequently, the consumption of sprouts in usual dietary may deliver countless health benefits. Ricegrass is a brand-new sprout which was shortly introduced as a substitution to wheatgrass, especially in high rice producing areas because it is being an economy ingredient as well as the purpose of utilizing low cost variety rice seeds. Additionally, young ricegrass has been described to possess beneficial biological properties included antioxidant [2] and DNA protective properties [3] which may probably due to numerous secondary metabolite compounds like phenolic compounds.

At the present time, the study on phytochemicals have become the foremost research issues in the field of functional foods. The development of efficient strategies to improve the level of useful metabolites in edible plants without gene modification are increasingly relevant and significant. Elicitation is one of the most effective approaches to induce the synthesis of bioactive secondary metabolites in plants, as plants automatically respond to all kind of unknown compounds to ensure their survival via the production of these protective substances [4]. The type of elicitor is varied from biotic to abiotic one. As known that minerals are the basic element requirement for all living cells. The bio-fortification is the procedure which normally use to increase the micronutrients content in plants during plantation by adding the mineral into soil or solution. Additionally, this technique can also be applied, as plant elicitation techniques using those minerals to induce the physiological changes and trigger the synthesis of phytochemical compounds which can possibly improve the biological properties of plants from the synergistic effects of phytochemical compounds and an increased content of minerals.

Selenium (Se) is an essential trace mineral required by human. It has a main function in the antioxidant system and claims for the outstanding efficiency among antioxidant minerals involving a large number of endogenously antioxidant enzymes [5]. Likewise, in plants Se is also known to offer a protective role against oxidative damage. Therefore, various plants worldwide have been 
bio-fortified to perform despite unusual condition such as drought stress, UV-B stress, even heavy metals stress [6- 8]. Moreover, the bio-fortification of Se at the appropriate level also showed the superior beneficial effects to some common plants, including the stimulation of total phenolic compounds accumulation in purple potatoes [9], an improvement of antioxidant and anticancer properties in green tea $[10,11]$, the increasing of glucosinolate and Se-methylselenocysteine content, which are the anticancer substances in broccoli sprouts and florets [12]. However, the ability of each plant to accumulate Se varies among species. Thus, the favourable level of fortified Se still needs to be studied.

As rice grain is the reference source of Se in diet, the accumulation of Se in their sprouts has yet to be performed. The bio-fortification of Se into ricegrass is a significant idea that is expected to provide a source of organic Se supplementation and stimulate the bioactive compounds content in plants, in addition to providing greater biological properties. Hereafter, the goal of this present study was to investigate the influence of different concentration of Se bio-fortification into rice grain on growth characteristics, Se content, nutritional components, bioactive compound contents included phenolic compounds, chlorophyll, carotenoid and ascorbic acid content as well as the anti-oxidative properties. Moreover, the activity of phenylalanine ammonia lyase (PAL), which was the initial enzymes responsible for phenolic compounds biosynthesis, was determined. The present study was meant to deliver advantageous evidence on level of Se fortified to rice grain to further produce Se bio-fortified ricegrass in the form of juice or juice powder as a functional food product.

\section{MATERIALS AND METHODS}

Plantation: Paddy rice (Oryza sativa L. cv. Chainat 1) obtained from the Phatthalung Rice Research Center, Thailand was soaked in water for $24 \mathrm{~h}$. After they were being drained and washed with distilled water, a total $100 \mathrm{~g}$ soaked rice seeds were spread on the plantation tray and left in darkness for $48 \mathrm{~h}$. Sodium selenite solutions varying from 0, 10, 20, 30, and $40 \mathrm{mg} \mathrm{Se} / \mathrm{L}$ were applied at ratio 1:1 v/w into germinated rice seeds. No apparent toxicity was observed based on the preliminary experiment (data not shown). Ricegrass were cultivated under natural light with a day/night average temperature of $33 / 25^{\circ} \mathrm{C}$, relative humidity $63 \pm 5.0 \%$ and photoperiod $12 / 12$ (day/night) and harvested at day 8 .

Growth measurement: The height of shoots throughout the plantation period was determined using calliper. Defects and plant characteristics were noted. After $8 \mathrm{~d}$ of plantation, plants were harvested, washed, and drained in the sieve for $2 \mathrm{~min}$, and then shoots and roots were separated before being taken to measure their fresh weight.

Nutritional composition: The nutritional composition of young ricegrass, including protein, fat, carbohydrate, ash, and fibre contents, were analyzed following the method of AOAC [13].

Selenium speciation analysis: Ricegrass were dried in the oven at $50^{\circ} \mathrm{C}$ until the weight was constant. Total Se content and inorganic Se content in the shoots were determined using induced coupled plasma optical electron spectrophotometer (ICP-OES), following the method of Dumont et al. [14]. For the total Se determination, $0.2 \mathrm{~g}$ of samples were digested with $3 \mathrm{ml}$ of concentrated 
$\mathrm{HNO}_{3}$ and $1 \mathrm{ml}$ of $30 \% \mathrm{H}_{2} \mathrm{O}_{2}$ in a digestive stove heated at $180^{\circ} \mathrm{C}$ for $1.5 \mathrm{~h}$. The digested product was reconstituted to $10 \mathrm{ml}$ with Milli-Q water and auto-sampled for total Se content. The inorganic Se content in ricegrass shoots was also determined by initially digesting $2 \mathrm{~g}$ samples with $3 \mathrm{ml}$ of $4 \mathrm{M} \mathrm{HCl}$ at $100^{\circ} \mathrm{C}$ for $10 \mathrm{~min}$ followed by the centrifugation at $2500 \times \mathrm{g}$ for $10 \mathrm{~min}$ at $4^{\circ} \mathrm{C}$ to remove debris. The supernatants were reconstituted to $10 \mathrm{ml}$ with Milli-Q water and auto-sampled for inorganic Se content. The organic Se content was calculated as the difference between the total Se and inorganic Se content respectively.

Chlorophyll and carotenoid content: The total chlorophyll content was analyzed using the defined method of Arnon [15] and carotenoid was calculated according to the Lichtenthaler and Wellburn [16] equation. One gram of fresh ricegrass were grounded in a mortar and with $0.1 \mathrm{~g}$ $\mathrm{CaCO}_{3}$ and sand. Afterwards, it was extracted with $80 \%$ acetone then filtrated and re-extracted until the green colour disappeared. Then the volume of extract solution with absolute acetone $(99.5 \%)$ to $100 \mathrm{ml}$ and the absorbance was measured with spectrophotometer at 470, 645, and 663 $\mathrm{nm}$. The concentration of pigments was calculated from the following equations when $\mathrm{A}$ is absorbance $(\mathrm{nm})$ : Total chlorophyll content was $20.2\left(\mathrm{~A}_{645}\right)+8.02\left(\mathrm{~A}_{663}\right)$, chlorophyll a $\left(\mathrm{C}_{\mathrm{a}}\right)$ content was12.7 $\left(\mathrm{A}_{663}\right)+2.69\left(\mathrm{~A}_{645}\right)$, chlorophyll b $\left(\mathrm{C}_{\mathrm{b}}\right)$ was $22.9\left(\mathrm{~A}_{645}\right)-4.68\left(\mathrm{~A}_{663}\right)$, and carotenoid content was $\left(1000\left(\mathrm{~A}_{470}\right)-3.27 \mathrm{C}_{\mathrm{a}}-104 \mathrm{C}_{\mathrm{b}}\right) / 229$.

Extraction: Ricegrass growing at various concentrations of sodium selenite fortification were extracted with water at ratio of 1:2 (w/v) using a juicer machine (Hurom DA-900) at room temperature. The samples were filtered with Whatman No. 4 filter paper to get rid of residues and followed by centrifugation at $10,000 \times \mathrm{g}$ for $20 \mathrm{~min}$. The supernatant was subjected to freeze drying and then stored at $4^{\circ} \mathrm{C}$ in dark bottle.

Ascorbic acid content: The ascorbic acid content of the sample was analyzed using the indophenol colorimetric method [13]. Aqueous extracts of the ricegrass were diluted with $2 \%$ metaphosphoric acid to the appropriate concentration. $5 \mathrm{ml}$ of diluted samples were added with $10 \mathrm{ml}$ of $1.7 \mathrm{mM} \mathrm{2,6}$ di-chloro-indophenol solution, mixed well and measured for the absorbance using spectrophotometer at $518 \mathrm{~nm}$. Ascorbic acid $(0-400 \mu \mathrm{g} / \mathrm{ml})$ was used as the standard.

Total extractable phenolic content: The total extractable phenolic content of ricegrass juice extracts were measured using a modified method of Singleton and Rossi [17]. Briefly, $20 \mu 1$ of the extract was added to 96-well microplate. Then, $100 \mu \mathrm{l}$ of Folin reagent $(10 \% \mathrm{v} / \mathrm{v})$ and $80 \mu \mathrm{l}$ of $\mathrm{Na}_{2} \mathrm{CO}_{3}(7.5 \% \mathrm{w} / \mathrm{v})$ were added and mixed thoroughly. After incubation for $30 \mathrm{~min}$ in the dark at ambient temperature, the absorbance was measured at $765 \mathrm{~nm}$ using the microplate reader. The total phenolic content was expressed as mg of pyrogallol equivalent (PYE) through the calibration curve.

Phenylalanine ammonia lyase (PAL) assay: Fresh ricegrass was extracted followed the method of Sunohara and Matsumoto [18] and the supernatant was used as an extract enzyme sample. Phenylalanine ammonia lyase (PAL) activity was determined by the modified method of Cheng and Breen [19]. Briefly, the reaction started from the mixing of $1 \mathrm{ml}$ of $14 \mathrm{mM}$ phenylalanine 
solution and $2.7 \mathrm{ml}$ of $50 \mathrm{mM}$ borate buffer $(\mathrm{pH} 8.8)$. After that $0.3 \mathrm{ml}$ of the extract enzyme sample was added and left for an hour. Thereafter, the reaction was stopped with $0.1 \mathrm{ml}$ of $6 \mathrm{~N}$ $\mathrm{HCl}$. The production of cinnanate from phenylalanine was measured by change in absorbance at $290 \mathrm{~nm}\left(E=9.63 \mathrm{mM}^{-1} \mathrm{~cm}^{-1}\right)$. Enzymes activity was calculated according to the calibration curve of protein content using bovine serum albumin (BSA) as a standard determined by the assay of Bradford [20].

\section{Anti-oxidative properties}

DPPH radical scavenging activity

1,1-diphenyl-2-picryl-hydrazyl (DPPH) assay was measured using the modified method of BrandWilliams et al. [21] . Briefly, $150 \mu \mathrm{l}$ of the extract was added with $150 \mu \mathrm{l}$ of $0.2 \mathrm{mM} \mathrm{DPPH}$ in $95 \%$ ethanol. The mixture was mixed and left to stand for $30 \mathrm{~min}$ in the dark. The absorbance was determined at $517 \mathrm{~nm}$ using the microplate reader. Standard curves were prepared and reported as mg pyrogallol equivalent (PYE)/g extract (1-5 $\mu \mathrm{g} / \mathrm{ml})$.

\section{ABTS radical scavenging activity}

2,2'-azino-bis (3-ethylbenzthiazoline-6-sulfonic acid) (ABTS) assay was determined followed the method of Arnao et al. [22]. Stock solutions consisted of $7.4 \mathrm{mM}$ ABTS solution and $2.5 \mathrm{mM}$ $\mathrm{K}_{2} \mathrm{~S}_{2} \mathrm{O}_{8}$ solution were prepared and equally mixed to generate ABTS radical (ABTS ${ }^{\circ}$ ). After allowing them to react for $12 \mathrm{~h}$ at room temperature in the dark, the radical solution was diluted to obtain an absorbance of $1.1 \pm 0.02$ at $734 \mathrm{~nm}$ before performing the assay. $15 \mu 1$ of extract was mixed with $285 \mu \mathrm{l}$ of ABTS $^{\circ}$ solution and left at room temperature for $2 \mathrm{~h}$ in the dark. The absorbance was measured at $734 \mathrm{~nm}$ using the microplate reader. Standard curves were prepared and reported as mg pyrogallol equivalent (PYE)/g extract $(5-25 \mu \mathrm{g} / \mathrm{ml})$.

\section{Ferric reducing antioxidant power (FRAP)}

The ferric reducing antioxidant power (FRAP) assay was performed according to method of Benzie and Strain [23]. Fresh FRAP solution was prepared from the mixture of $300 \mathrm{mM}$ acetate buffer $\mathrm{pH}$ 3.6, $10 \mathrm{mM}$ TPTZ (2, 4, 6- tripyridyl-s-triazine) solution in $40 \mathrm{mM} \mathrm{HCl}$ and $20 \mathrm{mM}$ $\mathrm{FeCl}_{3} .6 \mathrm{H}_{2} \mathrm{O}$ solution at the ratio $10: 1: 1(\mathrm{v} / \mathrm{v} / \mathrm{v})$ and then warmed at $37^{\circ} \mathrm{C}$ for $30 \mathrm{~min}$ before use. 15 $\mu \mathrm{l}$ extract was added with $285 \mu \mathrm{l}$ of FRAP solution and left to stand for $30 \mathrm{~min}$ in the dark. The absorbance was read at $593 \mathrm{~nm}$ using microplate reader. Standard curves were prepared and reported as mg pyrogallol equivalent (PYE)/g extract $(1-10 \mu \mathrm{g} / \mathrm{ml})$.

\section{Ferrous ion chelating activity (FCA)}

Ferrous ion chelating activity was determined using the method of Ebrahimzadeh et al. [24]. 277.5 $\mu \mathrm{l}$ of extract was mixed with $7.5 \mu \mathrm{l}$ of $2 \mathrm{mM} \mathrm{FeCl}_{2}$ and $15 \mu \mathrm{l}$ of $5 \mathrm{mM}$ ferrozine for $10 \mathrm{~min}$ at room temperature. The absorbance was read at $562 \mathrm{~nm}$ using microplate reader. A standard curve was prepared using EDTA. The activity was expressed as mg EDTA equivalent (EDTAE)/g extract $(20-40 \mu \mathrm{g} / \mathrm{ml})$.

Statistical analysis: Completely randomized design (CRD) was used throughout the study. All experimental data were presented as mean \pm standard deviation of three replications. Means were 
analyzed using the analysis of variance (ANOVA). The significant differences among means were determined by Duncan's multiple range test $(p<0.05)$ using SPSS for Windows (SPSS Inc, Chicago, IL).

\section{RESULTS AND DISCUSSION}

Growth measurement: The bio-fortification of sodium selenite ranging from 10 to $40 \mathrm{mg} \mathrm{Se} / \mathrm{L}$ did not affect the growth of ricegrass at day 1 of plantation (Figure 1). The results revealed that the plant height was plantation time dependant. Se fortified at $10 \mathrm{mg} \mathrm{Se} / \mathrm{L}$ into the germinated rice grain resulted in non-significant difference of shoot height to the control with marginally higher at the last 3 days $(\mathrm{p}<0.05)$. However, the fortification of Se at higher concentration from $20-40 \mathrm{mg}$ $\mathrm{Se} / \mathrm{L}$ appeared to reduce the growth rate determined as height particularly at $40 \mathrm{mg} \mathrm{Se} / \mathrm{L}$ treatment. This might indicate as a sign of excess amount of Se bio-fortified into ricegrass.

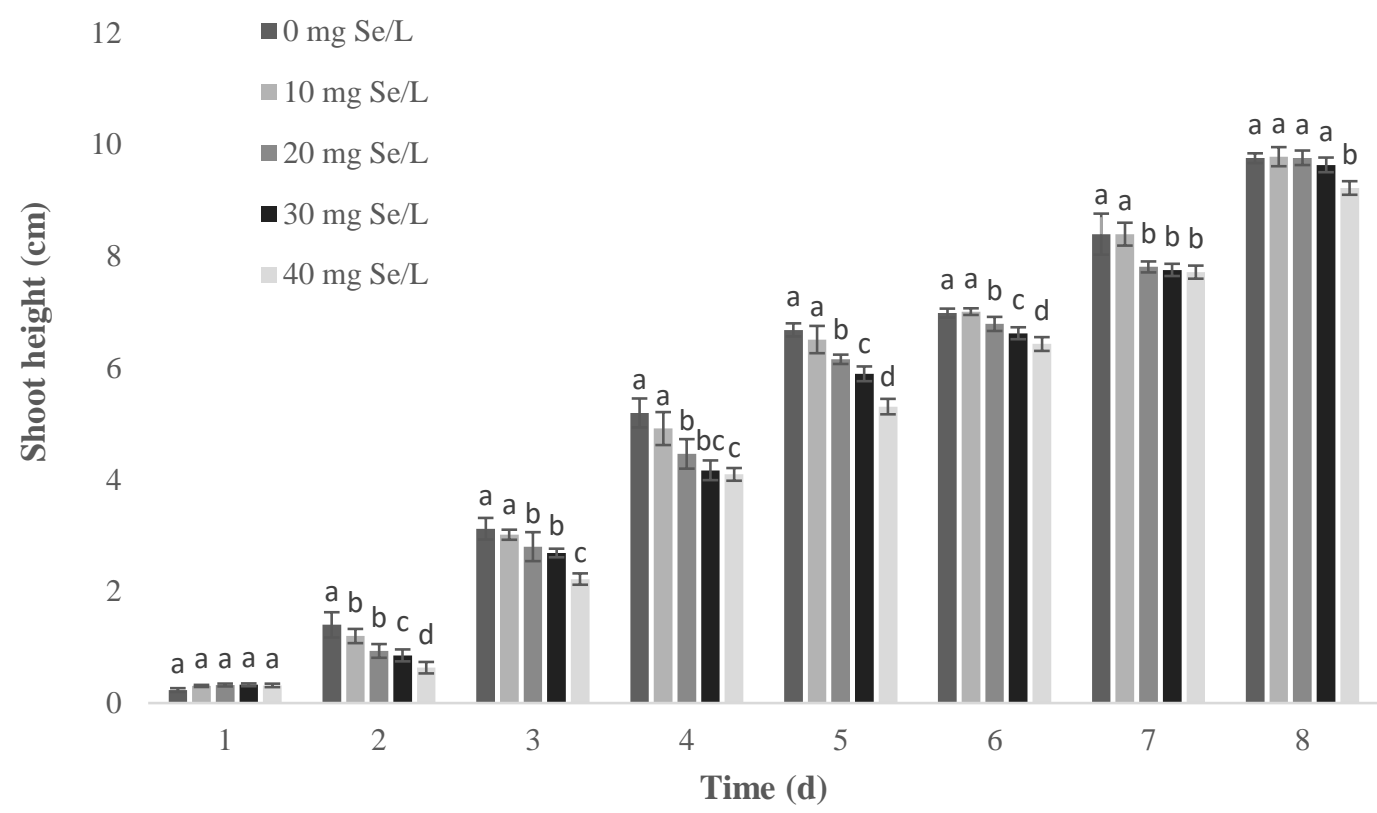

Figure 1. Effect of Se bio-fortification (0, 10, 20, 30 and $40 \mathrm{mg} \mathrm{Se} / \mathrm{L})$ on height of ricegrass shoots throughout $8 \mathrm{~d}$ of plantation.

The biomass of ricegrass shoot as affected of different Se bio-fortification were not significant different $(\mathrm{p}<0.05)$ from each other as shown in Table 1 . Only slightly reduction in treatment 30 and $40 \mathrm{mg} \mathrm{Se} / \mathrm{L}$ Se bio-fortification were observed. However, these two treatments reduced the biomass of the root part significantly, as root parts were noticed as the first part which directly contact to Se solution and absorbed greater amount of them. Moreover, while plantation at day 1 to day 3, these two treatments reflected offending smell which may represent the odor of volatize Se compounds. These may be a signal indicating the stress of plants grown at excess Se concentration. Se toxicity was reported to relate with various metabolic aberrations. As Se and sulfur (S) compounds are inter-related molecules [25], Se bio-fortification may promote the substitution to $\mathrm{S}$ compounds in protein structure and lead to the loss in its stability. Furthermore, an excess amount of Se, especially in inorganic form, was reported to act as pro-oxidant by reacting 
with tissue thiols to form seleno-trisulphides which generated the oxygen free radicals when they reacted with other thiols [26]. However, all living plants continued to struggle and acclimate themselves through the volatilization process in order to discard excess Se compounds in plant tissue to the environment by transforming Se into volatized forms called dimethyselenide and dimethydiselenide [27]. This may be the reason whether the plant height of using 10-30 mg Se/L was similar to the control at day 8 of plantation (Figure 1). As a result, all ricegrass Se fortification except for treatment $40 \mathrm{mg} \mathrm{Se} / \mathrm{L}$ grew and reached the similar range of height with no difference in shoot biomass at day 8 .

Table 1. Effect of Se bio-fortification (0, 10, 20, 30 and $40 \mathrm{mg} \mathrm{Se} / \mathrm{L})$ on biomass of ricegrass shoot and root parts.

\begin{tabular}{ccc}
\hline $\begin{array}{c}\text { Se bio-fortification } \\
(\mathbf{m g ~ S e} / \mathbf{L})\end{array}$ & $\begin{array}{c}\text { Root part biomass } \\
(\mathbf{g} \text { FW/100 g seeds })\end{array}$ & $\begin{array}{c}\text { Shoot biomass } \\
(\mathbf{g} \text { FW/100 g seeds })\end{array}$ \\
\hline 0 & $338.85 \pm 7.83^{\mathrm{a}}$ & $41.55 \pm 2.12^{\mathrm{a}}$ \\
10 & $337.83 \pm 13.52^{\mathrm{a}}$ & $41.23 \pm 2.25^{\mathrm{a}}$ \\
20 & $339.10 \pm 15.64^{\mathrm{a}}$ & $41.07 \pm 1.85^{\mathrm{a}}$ \\
30 & $307.41 \pm 12.11^{\mathrm{b}}$ & $39.78 \pm 1.90^{\mathrm{a}}$ \\
40 & $274.53 \pm 15.82^{\mathrm{c}}$ & $37.90 \pm 3.40^{\mathrm{a}}$ \\
\hline
\end{tabular}

Each value was expressed as the mean \pm standard deviation $(n=3)$. Different letters in the same column indicated significant differences $(\mathrm{p}<0.05)$. FW: fresh weight.

Nutritional compositions: The nutritional compositions of Se bio-fortified ricegrass shoots (Table 2) demonstrated an increase in protein and fat content at $10 \mathrm{mg} \mathrm{Se} / \mathrm{L}$ fortification while higher levels of Se treatment were reduced to less than that of the control. $10 \mathrm{mg} \mathrm{Se} / \mathrm{L}$ treatment may be the amount limit of Se that does not affect the development of plants. Therefore, Se promotes the accumulation of nitrogen $(\mathrm{N})$ compounds in ricegrass, which is the initial substrate of protein. However, excess of concentration will probably imbalance the pool of mineral and further effect the production of macronutrients. Moreover, the reduction in protein and fat concentrations due to high Se accumulation may be related to the incorporation of Se in nonprotein amino acids, including Se-methylselenocysteine by replacing S compounds in cysteine and methionine [28], thereby making these amino acids partly unavailable for protein synthesis. Furthermore, the reduction in the percentage of fat at high Se fortification treatment may be due to the substitution of Se to $\mathrm{S}$, which leads to the diminishing in activity of fatty acid synthatase and acetyl CoA carboxylase, which were enzymes having SH groups at the active site that played role in fat production [29]. The percentage of ash between treatments did not show any significant difference in all treatments. This may indicate the ability of the plants to equilibrate minerals status in their tissues as homeostatic phenomena. 
Table 2. Effect of Se bio-fortification (0, 10, 20, 30 and $40 \mathrm{mg} \mathrm{Se} / \mathrm{L})$ on nutritional compositions of ricegrass

\begin{tabular}{cccccc}
\hline $\begin{array}{c}\text { Se conc. } \\
(\mathrm{mg} \mathrm{Se} / \mathrm{L})\end{array}$ & \% Protein & \% Fat & \% Carb & \% Fiber & \% Ash \\
\hline $\mathbf{0}$ & $23.27 \pm 0.52^{\mathrm{a}}$ & $9.91 \pm 0.60^{\mathrm{b}}$ & $61.24 \pm 0.65^{\mathrm{c}}$ & $22.91 \pm 0.59^{\mathrm{ab}}$ & $5.58 \pm 0.22^{\mathrm{a}}$ \\
$\mathbf{1 0}$ & $23.88 \pm 0.16^{\mathrm{a}}$ & $12.16 \pm 0.37^{\mathrm{a}}$ & $58.56 \pm 0.69^{\mathrm{d}}$ & $22.86 \pm 0.44^{\mathrm{b}}$ & $5.39 \pm 0.19^{\mathrm{a}}$ \\
$\mathbf{2 0}$ & $22.65 \pm 0.64^{\mathrm{b}}$ & $9.62 \pm 1.06^{\mathrm{b}}$ & $62.34 \pm 0.23^{\mathrm{b}}$ & $23.96 \pm 0.13^{\mathrm{a}}$ & $5.39 \pm 0.35^{\mathrm{a}}$ \\
$\mathbf{3 0}$ & $22.53 \pm 0.06^{\mathrm{b}}$ & $8.28 \pm 0.61^{\mathrm{c}}$ & $63.88 \pm 0.56^{\mathrm{a}}$ & $23.66 \pm 0.90^{\mathrm{ab}}$ & $5.31 \pm 0.31^{\mathrm{a}}$ \\
$\mathbf{4 0}$ & $21.43 \pm 0.43^{\mathrm{c}}$ & $8.82 \pm 0.21^{\mathrm{bc}}$ & $64.28 \pm 0.26^{\mathrm{a}}$ & $23.23 \pm 0.28^{\mathrm{ab}}$ & $5.46 \pm 0.20^{\mathrm{a}}$ \\
\hline
\end{tabular}

Each value was expressed as the mean \pm standard deviation $(n=3)$. Different letters in the same column indicated significant differences $(\mathrm{p}<0.05)$.

Selenium content: The total Se content of rice shoots increased steadily, corresponding to an increased amount of exogenous sodium selenite supplementation in every treatment (Figure 2). The bio-fortification of Se can significantly increase Se content in the shoot of rice plant up to 529 $\%$ at $40 \mathrm{mg} \mathrm{Se} / \mathrm{L}$ fortification. Furthermore, the results indicated that Se was naturally found in the form of organic in ricegrass. With inorganic Se supplementation, plants demonstrated the ability to transform the inorganic Se to an organic form, which was supposed to be a safe form that is also highly bioavailable for human consumption. The fortification of Se at $20 \mathrm{mg} \mathrm{Se} / \mathrm{L}$ treatment appeared to be a boundary of ricegrass to accumulate Se in organic form since the fortification of higher dose (30 and $40 \mathrm{mg} \mathrm{Se} / \mathrm{L}$ ), Se in inorganic form was significantly accumulated. This may be due to the fact that protein and $\mathrm{S}$ containing compound contents in each plant was the key factor indicating how much Se can be accumulated in organic and inorganic form. Additionally, plants started to express some abnormal symptoms when the inorganic form content was over its homeostatic capacity.

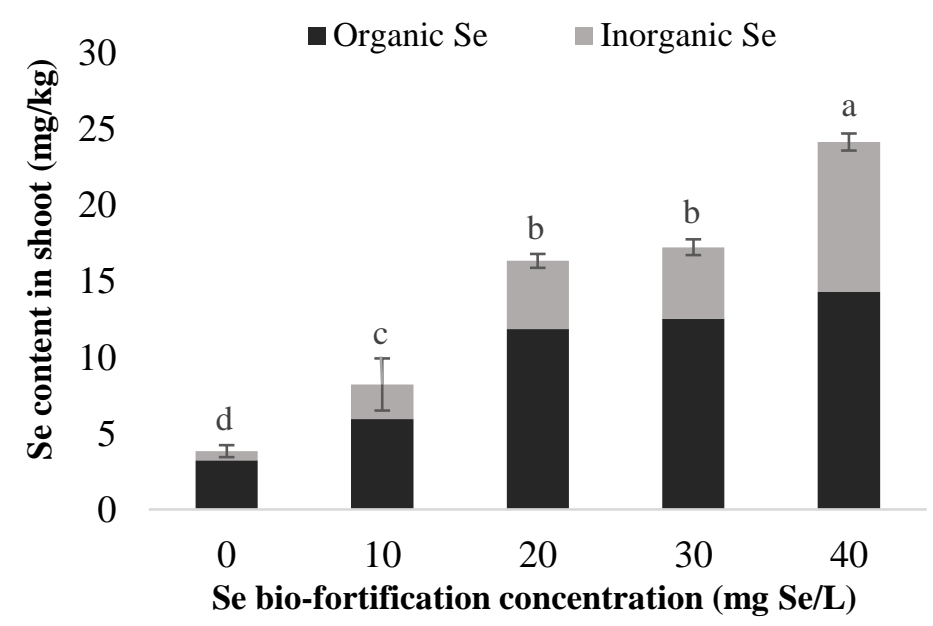

Figure 2. Effect of Se bio-fortification (0, 10, 20, 30 and $40 \mathrm{mg} \mathrm{Se} / \mathrm{L})$ on Se content of ricegrass shoots. Each value was expressed as the mean \pm standard deviation $(n=3)$. Different letters indicated significant differences $(\mathrm{p}<0.05)$. 
Bioactive compounds content: When using the bio-fortification as an elicitation technique, the improvement of bioactive compounds content may exert additional benefits to usual plants. The total chlorophyll content of ricegrass as affected by Se bio-fortification significantly decreased to the lowest at $20 \mathrm{mg} \mathrm{Se} / \mathrm{L}$ bio-fortification treatment and increased afterwards. Many studies suggested the role of Se was to promote the electron flow in respiratory, which thereby promotes the chlorophyll biosynthesis [30,31]. However, the results in this study were not consistent to those studies. The difference of these results may differentiate from genes and other factors in each plant sample, in addition to the individual path of plant development. The reduction in chlorophyll content in ricegrass may vary not from the direct effect of Se concentration but from its indirect effect by firstly managing other compounds, such as phenolic compounds. An increase of phenolic compounds may probably be induced by Se as an enhancer and further relate to a reduction in chlorophyll biosynthesis due to the competitive production between polyphenol and chlorophyll biosynthesis from similar substrate [32]. As can be seen in Table 5, the chlorophyll and total phenolic content was negatively significantly correlated $(\mathrm{p}<0.01)$. However, the level of carotenoids, which is one kind of protective substances in plants, increased to protect plant cell from stress stimuli, including excess Se. As a result, the plant required higher amounts of carotenoids to function via xanthophyll cycle to extenuating those kinds of abnormality [33].

The total extractable phenolic content (TPC) of ricegrass was slightly increased when fortified with Se at $10 \mathrm{mg} \mathrm{Se} / \mathrm{L}$ and $20 \mathrm{mg} \mathrm{Se} / \mathrm{L}$. However, the reversed effect was observed at higher dose (Figure 3). An increase of the total extractable phenolic content was significantly correlated with an increased level of phenylalanine ammonia lyase (PAL) activity $(\mathrm{p}<0.01)$ (Table 5). One possibility is that Se may influence the synthesis of phenolic compounds through a stimulation of this enzyme. PAL is the first and a key enzyme of the phenylpropanoid pathway involving the synthesis of benzoic acid and a variety of other phenol defense-related plant secondary metabolites [34]. However, PAL content was the highest at $20 \mathrm{mg} \mathrm{Se} / \mathrm{L}$ treatment, and the levels of TPC of the plant at $10 \mathrm{mg} \mathrm{Se} / \mathrm{L}$ and $20 \mathrm{mg} \mathrm{Se} / \mathrm{L}$ were similar. This may indicate slightly delaying time of enzymes response to the production of phenolic compounds. Additionally, the utilization of phenols may occur significantly for being an antioxidant during high growth condition. As known, the main antioxidant agents in plant induces ascorbic acid and/or vitamin $\mathrm{E}$ in addition to phenolic compounds. Another mechanism which can explain an improvement of TPC content may be due to the fact that $\mathrm{S}$ and Se are antagonists at similar routes of absorption by plant roots. Meanwhile, $\mathrm{N}$ and $\mathrm{S}$ are the major substrates for protein production. The accumulation of one mineral either $\mathrm{S}$ or $\mathrm{N}$ leads to the limitation of the other. Therefore, the addition of Se into plant may exert the accumulation of $\mathrm{N}$ in plants by enhancing amino acids and protein synthesis [35]. Phenylalanine is the main substrate for phenolic biosynthesis; consequently, Se supplementation at the proper dose may trigger the production of phenolic compounds, while higher doses may cause toxicity.

Ascorbic acid claims to be one kind of potent antioxidant molecules to defend against radicals in water soluble phase [36]. A reduction in ascorbic acid content was observed when a higher level of Se was fortified. This suggests that ascorbic acid was used by ricegrass as an antioxidant substance to protect, in contradiction to the pro-oxidant molecules induced by Se. Evidences in cactus pear treated with selenoferous soil also revealed the similar results that ascorbic acid content was reduced. Likewise, the level of phenolic compounds tended to higher afterwards [37]. This 
may propose the roles of ascorbic acid in plant as primary defensing substances. After the pool of it became low, plants may substitute it with other compounds, namely phenolics.

Table 3. Effect of Se bio-fortification (0, 10, 20, 30 and $40 \mathrm{mg} \mathrm{Se} / \mathrm{L})$ on bioactive compounds content of ricegrass shoot.

\begin{tabular}{ccccc}
\hline $\begin{array}{c}\text { Se conc. } \\
(\mathrm{mg} \mathrm{Se} / \mathrm{L})\end{array}$ & $\begin{array}{c}\text { Total Chlorophyll } \\
(\mathrm{mg} / \mathrm{g} \text { FW })\end{array}$ & $\begin{array}{c}\text { Carotenoids } \\
(\mathrm{mg} / \mathrm{g} \mathrm{FW})\end{array}$ & $\begin{array}{c}\text { Ascorbic acid } \\
(\mathrm{mg} / \mathrm{g} \mathrm{FW})\end{array}$ & $\begin{array}{c}\text { TPC } \\
(\mathrm{mg} \mathrm{PYE} / \mathrm{g} \text { extract })\end{array}$ \\
\hline 0 & $1.174 \pm 0.014^{\mathrm{a}}$ & $0.094 \pm 0.018^{\mathrm{bc}}$ & $0.243 \pm 0.002^{\mathrm{a}}$ & $20.47 \pm 0.15^{\mathrm{b}}$ \\
10 & $0.840 \pm 0.018^{\mathrm{c}}$ & $0.104 \pm 0.004^{\mathrm{ab}}$ & $0.234 \pm 0.001^{\mathrm{c}}$ & $21.82 \pm 0.48^{\mathrm{a}}$ \\
20 & $0.798 \pm 0.017^{\mathrm{c}}$ & $0.107 \pm 0.008^{\mathrm{a}}$ & $0.238 \pm 0.001^{\mathrm{b}}$ & $21.55 \pm 0.27^{\mathrm{a}}$ \\
30 & $0.804 \pm 0.051^{\mathrm{c}}$ & $0.094 \pm 0.010^{\mathrm{bc}}$ & $0.230 \pm 0.001^{\mathrm{d}}$ & $20.72 \pm 0.16^{\mathrm{b}}$ \\
40 & $0.971 \pm 0.012^{\mathrm{b}}$ & $0.090 \pm 0.005^{\mathrm{c}}$ & $0.218 \pm 0.001^{\mathrm{e}}$ & $20.35 \pm 0.27^{\mathrm{b}}$ \\
\hline
\end{tabular}

Each value was expressed as the mean \pm standard deviation $(n=3)$. Different letters in the same column indicated significant differences $(\mathrm{p}<0.05)$. TPC: Total extractable phenolic content FW: fresh weight. PYE: pyrogallol equivalent.

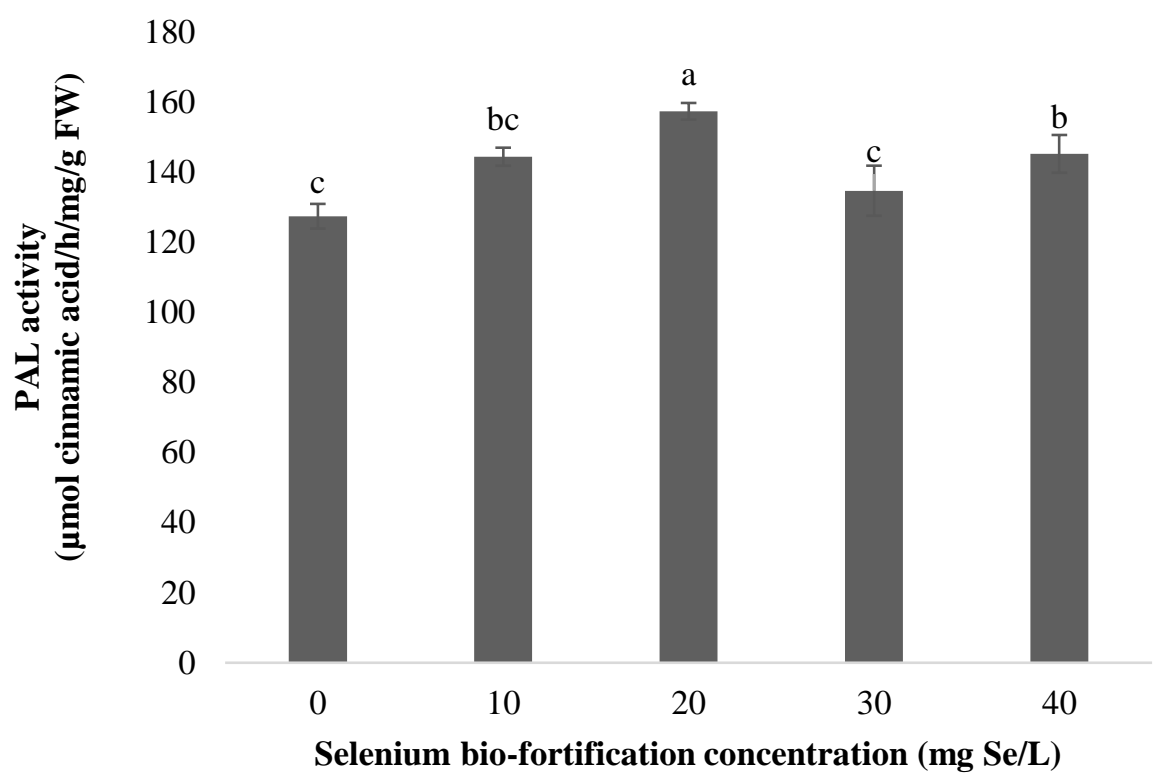

Figure 3. Effect of Se bio-fortification (0, 10, 20, 30 and $40 \mathrm{mg} \mathrm{Se} / \mathrm{L})$ on phenylalanine ammonia lyase (PAL) of ricegrass shoots. Each value was expressed as the mean \pm standard deviation $(n=3)$. Different letters indicated significant differences $(\mathrm{p}<0.05)$.

In vitro anti-oxidative properties: The antioxidant activities of ricegrass were detected using various systems to detect the action of different chemical structure of antioxidant compounds to the radical, in addition to different routes of antioxidant protection process. Se bio-fortification into germinated rice grain at $10 \mathrm{mg} \mathrm{Se} / \mathrm{L}$ resulted in the highest DPPH, ABTS, and FRAP activities 
(Table 4). However, the antioxidant activities of Se bio-fortified at 30 and $40 \mathrm{mg} \mathrm{Se} / \mathrm{L}$ seemed to be subsequently reduced.

Table 4. Effect of Se bio-fortification $(0,10,20,30$ and $40 \mathrm{mg} / \mathrm{L})$ on antioxidant activities of ricegrass shoot.

\begin{tabular}{ccccc}
\hline $\begin{array}{c}\text { Se conc. } \\
(\mathrm{mg} / \mathrm{L})\end{array}$ & $\begin{array}{c}\text { DPPH } \\
(\mathrm{mg} \text { PYE/g } \\
\text { extract })\end{array}$ & $\begin{array}{c}\text { ABTS } \\
(\mathrm{mg} \mathrm{PYE} / \mathrm{g} \\
\text { extract })\end{array}$ & $\begin{array}{c}\text { FRAP } \\
(\mathrm{mg} \text { PYE/g } \\
\text { extract })\end{array}$ & $\begin{array}{c}\text { FCA } \\
(\mu \text { mol EDTAE/g } \\
\text { extract })\end{array}$ \\
\hline 0 & $5.89 \pm 0.22^{\mathrm{c}}$ & $7.85 \pm 0.06^{\mathrm{a}}$ & $6.49 \pm 0.11^{\mathrm{b}}$ & $13.76 \pm 0.71^{\mathrm{b}}$ \\
10 & $6.82 \pm 0.10^{\mathrm{b}}$ & $8.02 \pm 0.08^{\mathrm{a}}$ & $6.72 \pm 0.17^{\mathrm{a}}$ & $14.55 \pm 1.29^{\mathrm{a}}$ \\
20 & $6.95 \pm 0.04^{\mathrm{a}}$ & $7.94 \pm 0.16^{\mathrm{a}}$ & $6.64 \pm 0.04^{\mathrm{ab}}$ & $7.41 \pm 0.48^{\mathrm{c}}$ \\
30 & $6.77 \pm 0.08^{\mathrm{b}}$ & $7.78 \pm 0.21^{\mathrm{b}}$ & $6.50 \pm 0.16^{\mathrm{b}}$ & $4.98 \pm 1.12^{\mathrm{d}}$ \\
40 & $6.57 \pm 0.07^{\mathrm{b}}$ & $7.18 \pm 0.06^{\mathrm{c}}$ & $6.55 \pm 0.12^{\mathrm{b}}$ & $4.53 \pm 0.95^{\mathrm{d}}$ \\
\hline
\end{tabular}

Each value was expressed as the mean \pm standard deviation $(n=3)$. Different letters in the same column indicated significant differences $(\mathrm{p}<0.05)$. PYE: pyrogallol equivalent. EDTAE: Ethylenediaminetetraacetic acid equivalent.

Plants are a rich source of antioxidant compounds. Various natural substances which provide antioxidant activities included ascorbic acid, tocopherols, and carotenoids. Moreover, the current topic also highlights the potential role of phytochemical components including flavonoids and phenolic acids as important antioxidant compounds in diet [38]. This may be due to the physicochemical of ascorbic acid, which are heat sensitive and easily oxidize. Thus, only a small amount of ascorbic acid was left in the sample. Furthermore, it was possible that the plants did not much produce and accumulate ascorbic acid, as rice is not a source of ascorbic acids like fruits are. Therefore, the substances which play roles in anti-oxidative properties of ricegrass was supposed to be phenolic compounds, since the treatment which was high in phenolics was to exhibit the highest ability of $\mathrm{H}$ and electron donor to radicals. This can be claimed due to the strong correlation between TPC and DPPH ( $<<0.01)$, as well as TPC and ABTS $(\mathrm{p}<0.05)$. Additionally, it was observed that the DPPH value was lower than the ABTS value. This may be due to the stronger steric effect of DPPH radical molecule and result in the difficulty of antioxidant compounds to react with its radical site [39]. The chelating activity of ricegrass, as effected by different Se supplementation, increased at $10 \mathrm{mg} \mathrm{Se} / \mathrm{L}$ treatment and then dramatically decreased. This may relate to the high level of inorganic Se accumulation in the samples and disturb the chelation between iron and antioxidant molecules. Nevertheless, these in vitro anti-oxidative measurement cannot detect the ability of Se as an antioxidant cofactor. Thus, further studies on cell cultures and in vivo study are needed to prove beneficial effects of Se on anti-oxidative properties. 
Table 5. Correlation analysis between bioactive compounds content, PAL activities and antioxidative properties of ricegrass

\begin{tabular}{llllllllll}
\hline Variables & $\mathbf{1}$ & $\mathbf{2}$ & $\mathbf{3}$ & $\mathbf{4}$ & $\mathbf{5}$ & $\mathbf{6}$ & $\mathbf{7}$ & $\mathbf{8}$ & $\mathbf{9}$ \\
\hline 1. TPC & 1 & & & & & & & \\
2. Chlorophyll & $-0.858^{* *}$ & 1 & & & & & & & \\
3. Carotenoids & 0.483 & $-0.626^{*}$ & 1 & & & & & \\
4. Ascorbic acid & -0.045 & -0.168 & 0.210 & 1 & & & & & \\
5. PAL & $0.645^{*}$ & $-0.644^{*}$ & $0.550^{*}$ & 0.219 & 1 & & & \\
6. DPPH & $0.880^{* *}$ & $-0.964^{* *}$ & $0.541^{*}$ & 0.064 & $0.686^{* *}$ & 1 & & \\
7. ABTS & $0.592^{*}$ & $-0.867^{* *}$ & $0.690^{* *}$ & 0.299 & 0.056 & $0.793^{* *}$ & 1 & \\
8. FRAP & 0.385 & -0.411 & 0.397 & -0.052 & 0.286 & 0.506 & 0.460 & 1 & \\
9. FCA & 0.340 & 0.034 & -0.244 & $-0.851^{* *}$ & -0.027 & 0.119 & -0.227 & 0.156 & 1 \\
\hline
\end{tabular}

Remark: ${ }^{*}$ and ${ }^{* *}$ means significant different at $\mathrm{p}<0.05$ and $\mathrm{p}<0.01$ respectively.

CONCLUSION: The present work demonstrated that the fortification of Se at $10 \mathrm{mg} / \mathrm{L}$ treatment was the ideal level to trigger the synthesis of phenolic compounds through phenylpropanoids pathway. Consequently, the exertion of high capacity opposed the oxidation process. However, the fortification of $40 \mathrm{mg} / \mathrm{L}$ Se treatment was significant for the production of Se plant foods, since ricegrass can accumulate up to 529\% higher level of Se content. Though further studies in cell cultures and in vivo are needed to confirm the actual synergistic properties of $\mathrm{Se}$ and phytochemicals in ricegrass on anti-oxidative properties, in addition to other bioactivities, it can be concluded that Se bio-fortified ricegrass can be considered a new functional food product, being rich in nutritional values that can promote wellness in human beings.

Abbreviations: TPC: Total extractable phenolic content; DPPH: 1,1-diphenyl-2-picryl-hydrazyl; ABTS: 2,2'-azino-bis (3-ethylbenzthiazoline-6-sulfonic acid); FRAP: Ferric reducing antioxidant power; FCA: Ferric ion chelating activity; Trolox: 6-hydroxy-2,5,7,8-tetramethylchroman-2carboxylic acid.

Competing interests: The authors have declared that no competing interests exist.

\section{Author's contributions:}

Rattanamanee Chomchan, Ph.D. candidate, is the major investigator, performed all experiments, the analysis and writing the manuscript.

Sunisa Siripongvutikorn, Ph.D. is an Assistant Professor of food technology. She provided vision and conceptualization for the research. She was also contributing to the study design, writing and verified the correction of manuscript. 
Panupong Puttarak, Ph.D. is a doctor of pharmaceutical sciences. He is a research coordinator who provided remarks, suggestion as well as verified the correction of manuscript.

Rungtip Rattanapon, M.Sc., is the research coordinator of this work who assisted in performing the experiments and writing the manuscript.

Acknowledgements: The authors would like to express sincerely to Patthalung Rice Research Center, Thailand proving the rice grain cultivar Chainat1. The authors are appreciative for the financial support from the Graduate School of Prince of Songkla University and Thailand Education Hub for southern region of ASEAN countries scholarship.

\section{REFERENCES:}

1. Pająk, P., Socha, R., Gałkowska, D., Rożnowski, J. and Fortuna, T. Phenolic profile and antioxidant activity in selected seeds and sprouts. Food Chem. 2014; 143:300-306.

2. Rattanapon, R., Siripongvutikorn, S., Usawakesmanee, W. and Thongraung, C. Improvement nutritional value and bioactivity of ricegrass as affected of priming induced by fish protein hydrolysate. Funct Foods Health Disease. 2016; 6:219-233.

3. Khanthapoka, P., Muangpromb, A. and Sukronga, S. Antioxidant activity and DNA protective properties of rice grass juices. Sci Asia. 2015; 41:119-129.

4. Namdeo, A. Plant cell elicitation for production of secondary metabolites: a review. Pharmacogn Rev. 2007; 1:69-79.

5. McDowell, L.R., Wilkinson, N., Madison, R. and Felix, T. (2007), the proceedings of the Florida Ruminant Nutrition Symposium. Best Western Gateway Grand. Gainesville, FL, pp. 30-31.

6. Kumar, A., Singh, R.P., Singh, P.K., Awasthi, S., Chakrabarty, D., Trivedi, P.K. and Tripathi, R.D. Selenium ameliorates arsenic induced oxidative stress through modulation of antioxidant enzymes and thiols in rice (Oryza sativa L.). Ecotoxicol. 2014; 23:11531163.

7. Yao, X., Chu, J. and Ba, C. Antioxidant responses of wheat seedlings to exogenous selenium supply under enhanced ultraviolet-B. Biol Trace Elem Res. 2010; 136:96-105.

8. Soleimanzadeh, H. Response of sunflower (Helianthus annuus L.) to selenium application under water stress. World Appl Sci J. 2012; 17:1115-1119.

9. Lei, C., Ma, Q., Tang, Q.Y., Ai, X.R., Zhou, Z., Yao, L., Wang, Y., Wang, Q. and Dong, J.Z. Sodium selenite regulates phenolics accumulation and tuber development of purple potatoes. Sci Hort. 2014; 165:142-147.

10. Xu, J., Yang, F., Chen, L., Hu, Y. and Hu, Q. Effect of selenium on increasing the antioxidant activity of tea leaves harvested during the early spring tea producing season. J Agric Food Chem. 2003; 51:1081-1084.

11. Molan, A., Flanagan, J., Wei, W. and Moughan, P. Selenium-containing green tea has higher antioxidant and prebiotic activities than regular green tea. Food Chem. 2009; 114:829-835.

12. Ávila, F.W., Faquin, V., Yang, Y., Ramos, S.J., Guilherme, L.R.G., Thannhauser, T.W. and $\mathrm{Li}, \mathrm{L}$. Assessment of the anticancer compounds Se-methylselenocysteine and 
glucosinolates in Se-biofortified broccoli (Brassica oleracea L. var. italica) sprouts and florets. J Agric Food Chem. 2013; 61:6216-6223.

13. AOAC. (2000) Official Method of Analysis. Association of Official Analytical Chemists. 17th ed, Washington D.C., USA.

14. Dumont, E., De Cremer, K., Van Hulle, M., Chéry, C.C., Vanhaecke, F. and Cornelis, R. Identification of the major selenium compound, Se-Methionine, in three yeast (Saccharomyces cerevisiae) dietary supplements by on-line narrowbore liquid chromatography-electrospray tandem mass spectrometry. J Chromatogr A. 2005; 1071:191-196.

15. Arnon, D.I. Copper enzymes in isolated chloroplasts. Polyphenoloxidase in Beta vulgaris. Plant Physiol. 1949; 24:1.

16. Lichtenthaler, H.K. and Wellburn, A.R. Determinations of total carotenoids and chlorophylls a and b of leaf extracts in different solvents. Biochem Soc Trans. 1983; 11:591-592.

17. Singleton, V. and Rossi, J.A. Colorimetry of total phenolics with phosphomolybdicphosphotungstic acid reagents. Am J Enol Viticul. 1965; 16:144-158.

18. Sunohara, Y. and Matsumoto, H. Oxidative injury induced by the herbicide quinclorac on Echinochloa oryzicola vasing and the involvement of antioxidative ability in its highly selective action in grass species. Plant Sci. 2004; 167:597-606.

19. Cheng, G.W. and Breen, P.J. Activity of phenylalanine ammonia-lyase (PAL) and concentrations of anthocyanins and phenolics in developing strawberry fruit. J Am Soc Hort Sci. 1991; 116:865-869.

20. Bradford, M.M. A rapid and sensitive method for the quantitation of microgram quantities of protein utilizing the principle of protein-dye binding. Anal Biochem. 1976; 72:248-254.

21. Brand-Williams, W., Cuvelier, M.-E. and Berset, C. Use of a free radical method to evaluate antioxidant activity. LWT-Food Sci Tech. 1995; 28:25-30.

22. Arnao, M.B., Cano, A. and Acosta, M. The hydrophilic and lipophilic contribution to total antioxidant activity. Food Chem. 2001; 73:239-244.

23. Benzie, I.F. and Strain, J. The ferric reducing ability of plasma (FRAP) as a measure of "antioxidant power": the FRAP assay. Anal Biochem. 1996; 239:70-76.

24. Ebrahimzadeh, M.A., Nabavi, S. and Nabavi, S. Correlation between the in vitro iron chelating activity and poly phenol and flavonoid contents of some medicinal plants. Pakistan J Biol Sci. 2009; 12:934.

25. Germ, M., Stibilj, V. and Kreft, I. Metabolic importance of selenium for plants. Eur J Plant Sci Biotechnol. 2007; 1:91-97.

26. Seko, Y., Saito, Y., Kitahara, J. and Imura, N. (1989), Selenium in biology and medicine. Springer, pp. 70-73.

27. Zayed, A., Lytle, C.M. and Terry, N. Accumulation and volatilization of different chemical species of selenium by plants. Planta. 1998; 206:284-292.

28. Nigam, S. and McConnell, W. Biosynthesis of Se-methylselenocysteine in lima beans. Phytochem. 1973; 12:359-362.

29. Terry, N., Zayed, A., De Souza, M. and Tarun, A. Selenium in higher plants. Annu Rev Plant Biol. 2000; 51:401-432. 
30. Dong, J.Z., Wang, Y., Wang, S.H., Yin, L.P., Xu, G.J., Zheng, C., Lei, C. and Zhang, M.Z. Selenium increases chlorogenic acid, chlorophyll and carotenoids of Lycium chinense leaves. J Sci Food Agric. 2013; 93:310-315.

31. Saffaryadi, A., Lahouti, M., Ganjeali, A. and Bayat, H. Impact of selenium supplementation on growth and selenium accumulation on spinach (Spinacia oleracea L.) plants. Not Sci Biol. 2012; 4:95-100.

32. Meyer S., Cerovic Z., Goulas Y., Montpied P., Demotes-mainard S., Bidel L., Moya I. and Dreyer E. Relationships between optically assessed polyphenols and chlorophyll contents, and leaf mass per area ratio in woody plants: a signature of the carbon-nitrogen balance within leaves? Plant Cell Environ 2006; 29:1338-1348.

33. Li G., Wan S., Zhou J., Yang Z. and Qin P. Leaf chlorophyll fluorescence, hyperspectral reflectance, pigments content, malondialdehyde and proline accumulation responses of castor bean (Ricinus communis L.) seedlings to salt stress levels. Ind Crop Prod 2010; 31:13-19.

34. Hahlbrock, K. and Scheel, D. Physiology and molecular biology of phenylpropanoid metabolism. Annu Rev Plant Biol. 1989; 40:347-369.

35. Barney, JRP and Bush L. Interaction of nitrate and sulfate reduction in tobacco: Influence of availability of nitrate and sulfate. J Plant Nutr 1985; 8:505-515.

36. Bendich, A., Machlin, L., Scandurra, O., Burton, G. and Wayner, D. The antioxidant role of vitamin C. Adv Free Rad Biol Med. 1986; 2:419-444.

37. Bañuelos, G.S., Stushnoff, C., Walse, S.S., Zuber, T., Yang, S.I., Pickering, I.J. and Freeman, J.L. Biofortified, selenium enriched, fruit and cladode from three Opuntia Cactus pear cultivars grown on agricultural drainage sediment for use in nutraceutical foods. Food Chem. 2012; 135:9-16.

38. Prior, R.L. and Cao, G. Antioxidant phytochemicals in fruits and vegetables: diet and health implications. Hort Sci. 2000; 35:588-592.

39. Prior, R. L., Wu, X. and Schaich, K. Standardized methods for the determination of antioxidant capacity and phenolics in foods and dietary supplements. J Agric Food Chem. 2005; 53:4290-4302. 